\title{
VARIATIONS IN SEED OIL AND FATTY ACID CONTENT OF DIFFERENT SOYBEAN GENOTYPES AND ITS COORELATION WITH SEED OIL
}

\author{
SHANKAR NEUPANE ${ }^{1}$, KRISHNA HARI DHAKAL ${ }^{2}$ \& RAJENDRA DARAI ${ }^{\mathbf{3}}$ \\ ${ }^{1}$ M. Sc., Scholar, Department of Genetics and Plant Breeding, Agriculture and Forestry University, \\ Rampur, Chitwan, Nepal \\ ${ }^{2}$ Assistant Professor and Chairman, Department of Genetics and Plant Breeding, Agriculture and \\ Forestry University, Rampur, Chitwan, Nepal \\ ${ }^{3}$ Senior Scientist and Research Scholar, National Grain Legumes Research
}

Programme, Khajura, Banke, Nepal

\begin{abstract}
The research was conducted at the agronomy block of the National Cattle Research Program, Rampur Chitwan, during the soybean growing season (July-November), 2015. The objective of this study was to analyze oil and fatty acid content of soybean seed and also find out the composition of oil and fatty acids and its correlation among the genotypes. Layout of the field was carried out in Randomized Complete Block Design (RCBD) within three replications and comprised of 15 exotic genotypes including check. Analysis of oil content was done in Department of Food Technology and Quality Control, Kathmandu is using a Soxhlet apparatus and the fatty acid content was analyzed in the College of Agriculture and Live Sciences, Kyungpook National University, South Korea uses gas chromatography. The highest average oil content was found in TGX1990-110FN (17.95\%) followed by TGX1989-68FN (17.41\%) and TGX1990-106FN (17.31\%). A highly significant difference was found among fifteen soybean genotypes in terms of five fatty acids. Highly negative correlation was found between the oleic acid and linoleic acid (-0.9821**); linolenic acid ($0.6591 \%$ ). Soybean normally contains $15 \%$ saturated fatty acid, $23 \%$ monounsaturated fatty acids and $62 \%$ polyunsaturated fatty acid. Desirable content of fatty acid in soybean oil by industries is dependent upon its use. High monounsaturated fatty acid, high saturated fatty acid and high polyunsaturated fatty acid or desirable for frying, baking and industrial purposes, respectively. But in this experiment, almost all the genotypes showed the fatty acid content suitable for normal vegetable oil.
\end{abstract}

KEYWORDS: Oil, Soybean, Fatty Acid \& Correlation

Received: Aug 26, 2017; Accepted: Sep 20, 2017; Published: Oct 16, 2017; Paper Id.: IJASROCT201765

\section{INTRODUCTION}

Soybean (Glycine max L. (Merrill), diploid chromosome $2 \mathrm{n}=40$ ) is the most important summer legume in terms of area, production and international trade belonging to the Leguminosae family. Soybean plays a very significant role in world agriculture. World high demand for soybean has been able to absorb ever-increasing production at prices that are profitable to the producers (Tefera, 2011). Soybean is a unique plant, which has oblong pods containing 2 to 4 seeds, with approximately 38\% protein, 18\% oil, 30\% carbohydrate, 14\% moisture, ash, and secondary component's contents. It is a rich source of vitamins (A, thiamin, riboflavin, pyridoxine and folic acid) and minerals (Fe, Zn, Mg, K, Ca, Mn, and Se), phytoestrogens and fibers (Liu, 1997; Anderson, Johnstone\& Cook-Newell, 1995; Reynolds, Chin, Lees, Nguyen, Bujnowski\& He, 2006). 
Soybean is the leading oilseed crop that is produced and consumed in the world. Since the 1960s, it has been a dominant oilseed crop produced and consumed in the world market (Smith \& Huyser, 1987). Soybean oil is also an important source of vegetable oil that is consumed mostly for human food (Glaudemans, Timmermans \& Rijkse, 1998) and supplies approximately $25 \%$ of the world's edible oils (Golbitz, 2003). The highest percentage of fatty acid in soybean oil is linoleic acid, followed in decreasing order by oleic, palmitic, linolenic, and stearic acid. Soybean oil also contains some minor fatty acids, including arachidic, behenic, palmitoleic, and Myristic acid (Liu, 1997). Normally, soybean oil contains higher linoleic acid (53\%), followed by oleic acid (23\%), palmitic acid (10\%) and stearic acid (5\%), respectively (Wilson, 2004). Polyunsaturated fatty acids found in soybean have gained considerable attention for their potential role in reducing the different heath risk factors for cardiovascular disease, the incidence of certain cancers, inflammatory diseases, diabetes and other disorders attributed to modern junky life styles and food habits. These benefits have been confirmed by epidemiological and clinical studies. (Barbalho\&Farinazzi-Machado, 2011)

Soybean is the third most important food legume of Nepal, grown either as intercrop with maize or levee paddy in bund sharing about $7 \%$ out of the total legumes area. Most importantly, it has diverse adaptability to varied agro-ecological zones with an altitude ranging from 200-2000m. Statistical data showed that soybean was cultivated on 23757 hectares of land and its production was $28237 \mathrm{mt}$ with the productivity of $1189 \mathrm{~kg} / \mathrm{ha}$ in Nepal (MoAD, 2013). Nepal imports huge amounts of raw materials of soybean for oil and feed purposes. In 2014 alone, soybean crude oil of Rupees 12 Arab, 48 crore 32 lakh was imported from India, Argentina, Brazil and Paraguay (MoAD, 2015). Not so many researchers have been carried out in Nepal in this sector.

Roasted soybean with maize is a popular breakfast and a main source of protein for the mid-hill people. Roasted split soybean with garlic, green chili and beaten rice is also very important Nepalese dishes for snacks during the fun time and in fact, it is the cheapest and best sources for Nepalese human diets. Soy protein is valued as a healthy protein due to containing a balanced proportion of all the important and essential amino acids required by the human body (Potter et al., 1998). Soybean is consumed in Nepal mainly as tiffin and a snack (Gupta, 1985) and green pods as vegetables. A huge variety of soybean made products like margarine, tofu, or soy cheese, soy milk, soy desserts, candies; pastry, cookies, cakes etc. is available in the market (Sharma, 1994).

The supply of oil and protein is becoming scarce, especially in the developing countries. The new source has been invented for the both protein and oil in the developing countries, in which soybean has been found as a good source for both due to the high content of both oil and protein (Hartwig \& Kilen, 1991).

\section{The Objectives of the Research are}

- To find out the oil and fatty acid content of soybean genotypes.

- To analyze the correlation among the different fatty acids

\section{MATERIALS AND METHODS}

The fifteen genotypes among the high yield performing on the site were collected from the National Grain Legumes Research Programme, Khajura, Banke, Nepal (Table 1). A Field experiment was evaluated in the field of National Cattle Research Programme, Rampur, Chitwan, during the main growing season from July, 2015 to November, 2015. The site is located $9.8 \mathrm{~km}$ South-West from Bharatpur, headquarter of Chitwan district. The precise latitude, 
longitude and altitude of Rampur is $27^{0} 39^{\prime} 0.45^{\prime \prime}$ North, $84^{\circ} 21^{\prime} 9.1^{\prime \prime}$ East and 228 masl, respectively. Geographically, the experimental location falls in the inner Terai region of Central Development Region of Nepal. The design of the experimental plot was Randomized Complete Block Design and the total treatments were fifteen with three replications. After harvesting, the seeds of different genotypes were collected from all the plots and brought to laboratory for oil and fatty acid analysis.

Table 1: List of Different Soybean Genotypes used for this Experiment

\begin{tabular}{|c|l|}
\hline S. N. & \multicolumn{1}{|c|}{ Genotype name } \\
\hline 1 & TGX1990-95F \\
\hline 2 & TGX1485-1D \\
\hline 3 & TGX1989-48FN \\
\hline 4 & TGX1990-40F \\
\hline 5 & PUJA $($ Check) \\
\hline 6 & TGX1990-52F \\
\hline 7 & TGX1990-110FN \\
\hline 8 & TGX1989-45F \\
\hline 9 & TGX1993-4FN \\
\hline 10 & TGX1990-106FN \\
\hline 11 & TGX1989-68FN \\
\hline 12 & TGX1990-80F \\
\hline 13 & TGX1990-114FN \\
\hline 14 & TGX1987-62F \\
\hline 15 & TGX1987-10F \\
\hline
\end{tabular}

\section{Method of Oil Extraction}

Two hundred and fifty gram of the seed sample was taken for oil extraction. $250 \mathrm{~g}$ of the sample was grinded into fine particles with mortar and pestle. The sample was quartered and 5-8g of powdered sample was obtained and crude oil was extracted with n-hexane in a Soxhlet apparatus for $12 \mathrm{hrs}$. The apparatus extracts, crude fat from the sample by recycling hot solvent, usually petroleum ether. The apparatus consists of 3 easy-to-fit parts, namely, the extraction tube (into which sample in a thimble is kept immersed in solvent for fat extraction), the receiving flask (which receives through a siphon system the solvent + extracted fat from the extraction tube and vaporizes the solvent selectively for recycling), and the condenser (which condenses the vaporized solvent onto the sample placed in the extraction tube). The recycling is done in a certain number of times (until the extraction is complete) and the fat recovered by evaporating away the solvent. After drying the solution with anhydrous sodium sulphate, solvent was removed by vacuum distillation at $30^{\circ} \mathrm{C}$. Oil percentages were determined by weight difference.

\section{Method of Fatty Acid Analysis}

Fatty acid of total oil for each genotype of soybean within each replication was determined by taking a seed sample. Ten seeds were randomly selected from each plot for fatty acid and they were crushed into pieces. Oil was extracted by placing crushed seeds in $5 \mathrm{ml}$ of chloroform: hexane: methanol $(8: 5: 2, \mathrm{v} / \mathrm{v} / \mathrm{v})$ overnight. Derivitization was done by transferring $100 \mu \mathrm{l}$ of extract to vials, and adding $75 \mu \mathrm{l}$ of methylating reagent ( $0.25 \mathrm{M}$ methanolic sodium methoxide: petroleum ether: ethyl ether [1:5:2, v/v/v]). Hexane was added to bring samples of approximately $1 \mathrm{ml}$. An Agilent (PaloAlto, CA) Series 7890 capillary gas chromatograph, fitted with a flame ionization detector $\left(275^{\circ} \mathrm{C}\right)$ was used with an AT-Silar capillary column (Alltech Associates, Deerfield, IL). Standard fatty acid mixtures (Animal and Vegetable Oil Reference Mixture 6, AOACS) were used as the calibration reference standards. 


\section{RESULTS AND DISCUSSIONS}

Statistically, there were highly significant differences among the 15 genotypes used in the research for the oil content. The average value of the oil content was $15.90 \%$ and the range was 13.30 17.95 (Table 2). Significantly highest oil content was found on genotype TGX1990-80F (17.95\%) which was statistically at par with TGX1990-110FN (17.43\%) and TGX1989-68FN (17.41\%) while the genotype with significantly lowest oil content was found in the standard check variety Puja (13.30\%). Oil content was varied in according to the genotypes available. Brim (1973) also mentioned that oil content varied due to the maternal parent of the genotype. Genetic and environmental factors also determine the oil content of soybeans (Escalante \& Wilcox, 1993); (Wolf et al., 1982). Thus the difference in the oil content had depended on the several factors, mainly the genotype and the environment.

Table 2: Performances of Fatty Acids of Soybean Genotypes

\begin{tabular}{|c|c|c|c|c|c|c|c|c|c|}
\hline S.N & Genotype & $\begin{array}{l}\text { Palmitic } \\
\text { Acid (\%) }\end{array}$ & $\begin{array}{c}\text { Stearic } \\
\text { Acid }(\%)\end{array}$ & $\begin{array}{c}\text { Oleic } \\
\text { Acid (\%) }\end{array}$ & $\begin{array}{l}\text { Linoleic } \\
\text { Acid }(\%)\end{array}$ & $\begin{array}{l}\text { Linolenic } \\
\text { Acid (\%) }\end{array}$ & Saturated Fatty Acid (\%) & $\begin{array}{c}\text { Unsaturated } \\
\text { Fatty Acid (\%) }\end{array}$ & Oil (\%) \\
\hline 1 & TGX1990-95F & 11.08 & 2.92 & 32.99 & 45.71 & 7.30 & 14.01 & 85.99 & 14.52 \\
\hline 2 & TGX1485-1D & 12.09 & 3.20 & 26.47 & 50.25 & 7.99 & 15.29 & 84.71 & 15.44 \\
\hline 3 & TGX1989-48FN & 12.14 & 3.57 & 21.15 & 53.78 & 9.36 & 15.71 & 84.29 & 16.51 \\
\hline 4 & TGX1990-40F & 12.01 & 3.91 & 25.77 & 50.28 & 8.03 & 15.92 & 84.09 & 16.42 \\
\hline 5 & TGX1990-110FN & 12.25 & 2.92 & 33.21 & 45.26 & 6.36 & 15.18 & 84.82 & 17.43 \\
\hline 6 & TGX1990-52F & 11.13 & 2.94 & 25.89 & 51.02 & 9.02 & 14.07 & 85.93 & 15.51 \\
\hline 7 & Puja & 11.67 & 3.40 & 23.00 & 55.10 & 6.93 & 15.07 & 85.03 & 13.30 \\
\hline 8 & TGX1989-45F & 12.21 & 2.93 & 28.32 & 48.52 & 8.02 & 15.14 & 84.86 & 15.69 \\
\hline 9 & TGX1993-4FN & 11.83 & 3.07 & 32.29 & 45.18 & 7.63 & 14.90 & 85.10 & 14.28 \\
\hline 10 & TGX1990-106FN & 10.89 & 2.77 & 35.17 & 43.84 & 7.34 & 13.65 & 86.35 & 17.32 \\
\hline 11 & TGX1989-68FN & 11.76 & 3.46 & 29.63 & 47.87 & 7.28 & 15.22 & 84.78 & 17.41 \\
\hline 12 & TGX1990-80F & 11.76 & 2.86 & 36.06 & 42.83 & 6.49 & 14.62 & 85.38 & 17.95 \\
\hline 13 & TGX1990-114FN & 11.68 & 3.35 & 23.31 & 53.13 & 8.52 & 15.03 & 84.97 & 16.47 \\
\hline 14 & TGX1987-62F & 10.43 & 2.88 & 23.03 & 54.85 & 8.82 & 13.30 & 86.70 & 14.70 \\
\hline 15 & TGX1987-10F & 11.51 & 3.34 & 28.82 & 49.36 & 6.98 & 14.85 & 85.15 & 15.56 \\
\hline Mean & & 11.63 & 3.17 & 28.34 & 49.13 & 7.74 & 14.8 & 85.21 & 15.90 \\
\hline F-test(P-value) & & $1.53 \mathrm{e}^{-15 * 4}$ & $0.0017^{* *}$ & $1.59 \mathrm{e}^{-5 * 4}$ & $5.32 \mathrm{e}^{-64 *}$ & $1.95 \mathrm{e}^{-6 * *}$ & $0.00018 * *$ & $0.00018 * *$ & $\begin{array}{c}1.532 \mathrm{e}^{-} \\
15 * 4\end{array}$ \\
\hline $\mathrm{LSD}_{0.05}$ & & 0.81 & 0.37 & 5.15 & 4.10 & 0.86 & 0.97 & 0.97 & 0.81 \\
\hline $\mathrm{CV}(\%)$ & & 4.16 & 7.06 & 10.87 & 5.00 & 6.65 & 3.90 & 0.68 & 4.16 \\
\hline
\end{tabular}

Statistically significant differences were observed in the different five essential fatty acids of soybean oil. There was mainly a significant difference in the palmitic acid, stearic acid, oleic acid, linoleic acid and linolenic acid at the $1 \%$ level of significance. These results revealed that significant difference was observed in the different saturated and unsaturated acids (Table 2). Significantly highest palmitic acid was observed in the genotype TGX1990-110FN (12.25\%) and it was statistically at par with the genotypes TGX1989-45F (12.21\%), TGX1989-48FN (12.14\%), TGX1485-1D (12.09\%) and TGX1990-40F (12.01\%) while the significantly lowest palmitic was observed in the genotype TGX1987$62 \mathrm{~F}(10.43 \%)$. The highest stearic acid was observed in the genotype TGX1990-40F (3.91\%), while the lowest stearic acid content was observed in the genotype TGX1990-106FN (2.77\%). TGX1990-80F (36.06\%) had the highest oleic acid content, which was statistically at par with TGX1990-106FN (35.17\%), while TGX1989-48FN (21.15\%) had the lowest oleic acid content. The high linoleic acid content was found in the genotype Puja (55.10\%) and it was statistically at par with TGX1987-62F (54.85\%). Similarly, the low linoleic acid content was observed in TGX1990-80F (42.83\%). The high linolenic acid content was found in the genotype TGX1989-48FN (9.36\%), which was statistically at par with TGX199052F (9.02\%), while the lowest linolenic acid content was found in the genotype TGX1990-110FN (6.36\%). Soybean oil and the fatty acids produce the oil content and these quantitative traits are influenced by many environmental and genetic factors. Oil composition is primarily determined by the genotype of the maternal parent as reported by Brim, 1973. Jokic et al.,(2013) also suggested that there were significant differences between the fatty acids of soybean oil. The five fatty acids were the only variables to have a significant genotype effect (Farno, 2005). 
Regarding the correlation coefficients between the individual unsaturated fatty acids, negative and highly significant correlation was observed, between oleic acid with both the polyunsaturated acids (linoleic and linolenic acids) (Table 3).

Table 3: Pearson's Product-Moment Correlation between the Different Fatty Acids and Oil Content of Soybean

\begin{tabular}{|l|c|c|c|c|c|c|}
\hline \multicolumn{1}{|c|}{ Parameters } & Oleic Acid & $\begin{array}{c}\text { Linoleic } \\
\text { Acid }\end{array}$ & $\begin{array}{c}\text { Linolenic } \\
\text { Acid }\end{array}$ & Palmitic Acid & Stearic Acid & Oil \\
\hline Oleic Acid & 1 & $-0.9821^{* *}$ & $-0.6591^{* *}$ & -0.2133 & $-0.5338^{* *}$ & $0.3251^{*}$ \\
\hline Linoleic Acid & & 1 & $0.5785^{* *}$ & 0.1135 & $0.4656^{* *}$ & $-0.3956^{* *}$ \\
\hline Linolenic Acid & & & 1 & -0.1596 & 0.1841 & -0.1277 \\
\hline Palmitic Acid & & & & 1 & $0.3515^{*}$ & 0.2086 \\
\hline Stearic Acid & & & & & 1 & 0.0234 \\
\hline Oil & & & & & & 1 \\
\hline
\end{tabular}

Note: $* *$ and $*$ indicates significant at $1 \%$ and $5 \%$ level of significance

Based on the correlation between the different fatty acids, negative correlation and highly significant with the linoleic acid $(\mathrm{r}=-0.9821, \mathrm{P} \leq$. 01). In the same way, oleic acid had also a significant negative correlation with linolenic acid $(\mathrm{r}=-0.6591, \mathrm{P} \leq .01)$ and also with stearic acid $(\mathrm{r}=-0.5338, \mathrm{P} \leq .01)$. Similarly, linoleic and linolenic acids were positively and significantly correlated with each other $(\mathrm{r}=0.5785 . \mathrm{P} \leq$. 01). This was confirmed by the report of Dhakal et al., (2006). In the same way the similar results were found by Burton, Wilson \& Brim (1983) and Liu et al., (1995). There was also the positive correlation between the oil content and oleic. The negative significant correlation was observed between oil and linolenic acid. This was supported by Dhakalet al., (2006). The correlation between the oleic and palmitic acid is negative, but not significantly correlated. The findings of Ahire (2012) and Bachlava, Burton, Brownie, Wang, Auclair\& Cardinal (2008) pointed out that the oleic and palmitic were significantly negatively correlated. In the same way oleic acid and stearic acids $(\mathrm{r}=-0.5338, \mathrm{P} \leq .01)$ were significantly negatively, correlated to each other which was in similar findings of Ahire (2012) and of Bachlavaet al., (2008) in FAE population. Palmitic acid was positively and significantly associated with the stearic acid $(\mathrm{r}=0.3515, \mathrm{P} \leq .05)$ and positively associated with the oil content, but it was not significantly associated $(\mathrm{r}=0.2086)$. Linoleic was positively and highly significantly correlated with stearic acid $(\mathrm{r}=0.4656, \mathrm{P} \leq .01)$ and similarly linolenic and stearic acid were positively correlated to each other. This was supported by the findings of Bachlava et al., (2008) in FAE population both genetically and phenotypically. However, negative correlation between stearic and linoleic and linolenic acid were also recorded by Maestriet al.,1998 and Farno, 2005. Regarding the correlation coefficient, palmitic acid was found to be stronger and positively correlated with stearic acid $(\mathrm{r}=0.3515, \mathrm{P} \leq$. 05) and it was supported by Ahire (2012) and Maestri et al., (1998). Oil and stearic acid were positively correlated, during the research and is supported by Bachlava et al., (2008) in FAF population. In the same way oil and palmitic acid were also positively correlated and this was in accordance with the work of Bachlavaet al., (2008) in FAE population.

\section{CONCLUSIONS}

In the context of oil content, soybean genotype TGX1990-80F had the highest oil content i. e. 17.95\%, followed by TGX1990-110FN, TGX1989-68FN (17.41\%) and TGX1990-106FN (17.31\%). In the case of fatty acids contents and the quality of oil content, genotypeTGX1987-62F had the highest \% of unsaturated fatty acid i. e. 86.70. Similarly, the research results concluded that those genotypes containing the highest unsaturated fatty acid gave the lowest saturated fatty acids. There were highly significant differences among the fifteen soybean genotypes in terms of five fatty acids. Similarly, there was a negative correlation between the oleic acid and linoleic acid and breeders can incorporate the trait by the use of 
genetic engineering (modification) of the hybridization program so as to help in the production of industrially important soybean oil. In the light, almost all the genotypes showed the fatty acid content suitable for normal vegetable oil. Thus, this study was benchmarked for future breeding works to develop the high oil content ideal genotype and may be used as the parent lines in the further quality breeding program.

\section{ACKNOWLEDGEMENT}

I am grateful to acknowledge the National Agricultural Research and Development Fund (NARDF), Singh Durbar Plaza, Kathmandu for providing the required funds during my research works. I would also like to thank Department of Food Technology and Quality Control, Kathmandu for timely help in the oil content analysis. Sincere thanks to Associate Professor Lee Jeong Dong, College of Agriculture and Live Sciences, Kyungpook National University, Republic of Korea for helping me in the fatty acid analysis.

\section{REFERENCES}

1. Ahire, D. D. (2012). Correlation studies and coefficient of variation among fatty acids and oil quality parameters in soybean mutants. Bioremediation, Biodiversity and Bioavailability, 6, 107-12.

2. Anderson, J. W., Johnstone, B. M., \& Cook-Newell, M. E. (1995). Meta-analysis of the effects of soy protein intake on serum lipids. New England Journal of Medicine, 333(5), 276-282.

3. Bachlava, E., Burton, J. W., Brownie, C., Wang, S., Auclair, J., \& Cardinal, A. J. (2008). Heritability of oleic acid content in soybean seed oil and its genetic correlation with fatty acid and agronomic traits. Crop science, 48(5), 1764-1772.

4. Barbalho, S. M., \& Farinazzi-Machado, M. V. (2011). Soybean: Food or Remedy?. Intech Open Access Publisher.

5. Brim, C. A. (1973). Quantitative genetics and breeding. Soybeans: Improvement, production, and uses. Agronomy Monograph 16, 155-186.

6. Burton, J. W., Wilson, R. F., \& Brim, C. A. (1983). Recurrent selection in soybeans. IV. Selection for increased oleic acid percentage in seed oil. Crop science, 23(4), 744-747.

7. Dhakal, K. H., Jeong, Y. S., Beak, I. Y., Kang, N. S., Yeo, Y. K. \& Hwang, Y. H. (2005). Composition of oil and fatty acid in sprout and yield soybeans for specific food and industrial applications. Journal of Korean Breeding 38 (4), 236-241.

8. Farno, L. A. (2005). Oil and fatty acid profiles of soybeans (maturity groups IV, V, and VI). Website: http://hdl.handle.net/11244/7726

9. Farno, L. A. (2005). Oil and fatty acid profiles of soybeans (maturity groups IV, V, and VI). Website: http://hdl.handle.net/11244/7726

10. Glaudemans, H. D., Timmermans, M. M. J., \& Rijkse, H. (1998). The world of edible oils. Rabobank International Marketing, Utrecht, the Netherlands, 1-5.

11. Golbitz, P. (2003). Soya \& Oilseed Bluebook, Soyatechnology Incorporation., Bar Harbor, ME, USA

12. Gupta, U.S. (1985). Performance of some cultivar of soybean (Glycine max. L. Merr.) In: Journal of Agriculture and Animal Science Volume 6: 89-92.

13. Hartwig, E. E., \& Kilen, T. C. (1991). Yield and composition of soybean seed from parents with different protein, similar yield. Crop science, 31(2), 290-292.

14. Jokic, S., Sudar, R., Svilovic, S., Vidovic, S., Bilic, M., Velic, D., \& Jurkovic, V. (2013). Fatty acid composition of oil obtained 
from soybeans by extraction with supercritical carbon dioxide. Czech Journal of Food Science, 31(2).

15. Liu, K. (1997). Soybeans chemistry technology and utilization. 2. ed. New York: Chapman \& Hall. 532p.

16. Liu, K., Brown, E. A., \& Orthoefer, F. (1995). Fatty acid composition within each structural part and section of a soybean seed. Journal of Agricultural and Food Chemistry, 43(2), 381-383.

17. Maestri, D. M., Guzman, G. A., \& Giorda, L. M. (1998). Correlation between seed size, protein and oil contents, and fatty acid composition in soybean genotypes. Grasas y aceites, 49(5-6), 450-453.

18. Ministry of Agricultural Development, (2013). Agri-Business Promotion and Statistics, Agri-Statics Division, Sigha Durbar, Kathmandu, Nepal.

19. Ministry of Agricultural Development, (2015). Agri-Business Promotion and Statistics Division, Agri-Statics Division, Sigha Durbar, Kathmandu, Nepal.

20. Potter S. M, Baum JA, Teng H, Stillman RJ, Shay NF \& Erdman JW (1998). Soy protein and isoflavones: their effects on blood lipids and bone density in postmenopausal women.

21. Reynolds, K., Chin, A., Lees, K. A., Nguyen, A., Bujnowski, D., \& He, J. (2006). A meta-analysis of the effect of soy protein supplementation on serum lipids. The American Journal of Cardiology, 98(5), 633-640.

22. Sharma, K. P. (1994). Soybean production in Nepal: Past achievements and future prospects. Journal of Institute of Agriculture and Animal Sciences, 15, 19-26.

23. Smith, K. J., \& Huyser, W. (1987). World distribution and significance of soybean. Food and Agriculture Organization.

24. Tefera, H. (2011). Breeding for Promiscuous Soybeans at IITA. Intech Open Access Publisher.

25. Wilson, R. F. (2004a) Seed Composition. In: H. R. Boerma and J. E. Specht (Eds), Soybeans: Improvement, Production, and Uses. Agronomy Monographs 3rd ed. No. 16, ASA-CSSASSSA,Madison, WI, USA, pp. 621-677. 
